\title{
Re-Evaluation of Acquired Epidermodysplasia Verruciformis in Kidney Transplant Recipients*
}

\author{
Khalifa E. Sharquie ${ }^{1 \#}$, Adil A. Noaimi ${ }^{2}$, Ali A. Al-Jobori ${ }^{3}$ \\ ${ }^{1}$ Chairman of Scientific Council of Dermatology and Venereology_-Iraqi Board for Medical Specializations, Baghdad, Iraq; ${ }^{2}$ Department \\ of Dermatology and Venereology, College of Medicine, University of Baghdad, Baghdad, Iraq; ${ }^{3}$ Department of Dermatology and \\ Venereology, Baghdad Teaching Hospital, Medical City, Baghdad, Iraq. \\ Email: "ksharquie@yahoo.co.uk, adilnoaimi@yahoo.com, ali60aljobori@yahoo.com
}

Received March 2 $2^{\text {nd }}, 2012$; revised April $5^{\text {th }}, 2012$; accepted April 16 ${ }^{\text {th }}, 2012$

\begin{abstract}
Background: Epidermodysplasia verruciformis (EV) is a skin disease associated with numerous early onset viral warts on the sun exposed parts of the body that usually progress into different skin malignancies. Kidney transplant patients are also commonly associated with viral warts that might change into skin cancers. Objective: To re-evaluate all features of the acquired epidermodysplasia verruciformis in kidney transplant patients in comparison with healthy individuals. Patients and Methods: This case controlled study that included 100 patients with kidney transplantation (87 males, 13 females) their ages ranged from $14-70$ (46.65 \pm 4.74$)$ years and was done in kidney Transplantation Centers in Baghdad and Al-Karma Teaching Hospitals from June 2009 - August 2010. Patients included were receiving multiple immunosuppressive drugs like azathioprine, prednisolone, cyclosporine, mycophenolate mofetil ranged from 6 months 25 years. One hundred healthy individuals ( 70 males, 30 females), there ages ranged from $14-73(41.63 \pm 9.55)$ years, had been examined as a control for the presence of viral warts and tumors. These control cases had been taken randomly from general population in multiple regions in Baghdad. Results: Forty (40\%) patients out of one hundred kidney transplant patients had viral warts and were seen in $9(9 \%)$ of control group and there was statistically significant difference between patients and control cases ( $\mathrm{P}$ value $<0.00001)$. Most of the viral warts were multiple and of the verrucae vulgaris type and were mainly located on the exposed areas of the body, mostly on the face and dorsa of the hands. Solar keratosis admixed with viral warts were found in 14 out of 100 kidney transplant patients. Skin malignancies in these fourteenth patients were observed in $6(42.14 \%)$ cases: 2 squamous cell carcinoma (SCC) and 4 basal cell carcinoma (BCC) and these were mainly located on the exposed areas of the body, mostly on the face and dorsa of the hands. No skin malignancies were observed in control group. Conclusions: Kidney transplant recipients had all the features that simulate the inherited epidermodysplasia verruciformis.
\end{abstract}

Keywords: Acquired Epidermodysplasia Verruciformisin; Kidney Transplant; Tumors

\section{Introduction}

Epidermodysplasia verruciformis (EV) is an inherited autosomal recessive gene disorder in which there is early onset, numerous, widespread, persistent, and refractory infection with human papilloma virus (HPV) [1-4]. The individual lesions typically have either the appearance of that warts or flat scaly red-brown macules, resemble lesions of pityriasis versicolor or pityriasis rosea. The first type of lesion is usually caused by the same HPV types as those found in flat warts in the general population (e.g. HPV-3 \& 10), while the second one is usually caused by EV HPV types (e.g. HPV-5, 8, 9, 12, 14, 15, 17, 19-25, 28, 29, 36-38, 47, 49 and 50) [2-7]. There may be more

\footnotetext{
*This study was an independent study and not funded by any of the drug companies.

${ }^{\#}$ Corresponding author.
}

than one HPV type in the same patient $[5,6]$. The pathogenesis of this syndrome is unknown but is felt to be a specific defect of cell mediated immunity $[2-4,8]$.

Some EV patients are at high risk of developing cutaneous squamous cell carcinoma (SCC) [1-4,9]. Although, pityriasis like lesions caused by any EV type may be at increased risk of becoming malignant, the risk appears to be greatest for those caused by HPV 5, 8 and 47 types $[1-4,6,9]$. The lesions of individuals with $\mathrm{EV}$ who have only flat warts caused by non-EV HPV types do not seem to be at increased risk of becoming malignant. Squamous cell carcinomas develop in $30 \%-60 \%$ patients. Most often, skin cancers appear on sun exposed surfaces, but they can appear on any parts of the body. They begin to appear at ages $20-40$ years. HPV 5, 8 and 47 are found in more than $90 \%$ of EV skin cancers. The 
squamous cell carcinoma may appear de-novo but usually appear on the background of numerous actinic keratosis and lesions of Bowen's disease, locally and usually aggressive [1-4].

The aim of the present work is to re-evaluate the clinical features of the acquired epidermodysplasia verruciformisin in kidney transplant recipients.

\section{Patients and Methods}

This case controlled study that included 100 patients with kidney transplantation ( 87 males, 13 females) their ages ranged from 14 - 70 years with a mean \pm SD of $46.65 \pm$ 4.74 years. This was carried out in kidney Transplantation Centers in Baghdad and Al-Karma Teaching Hospitals from June 2009 - August 2010. All patients with kidney transplant were receiving multiple immunosuppressive drugs like azathioprine, prednisolone, cyclosporine, mycophenolate mofetil ranged from 6 months - 25 years. They consisted of rapidly decreasing doses of intravenous methylprednisolone succinate for the first 3 days followed by oral prednisolone $60 \mathrm{mg}$ /day tapered slowly to a maintenance dose of $10-20 \mathrm{mg} /$ day every other day. While azathioprine was given at doses were ranging from $1-3 \mathrm{mg} / \mathrm{kg} /$ day according to the white blood cell count. Cyclosporine, in combination with azathioprine was also given orally starting with $8-10 \mathrm{mg} / \mathrm{kg} /$ day, decreased every two weeks by $2 \mathrm{mg} / \mathrm{kg} /$ day to be continued in a maintenance dose of $5 \mathrm{mg} / \mathrm{kg} /$ day. Mycophenolate mofetal was added with other immunosuppression in a dose 1 $2 \mathrm{gm} /$ day. History was taken from all patients including all relevant points. These patients were divided into 3 groups according to the duration of immunosuppressive therapy: Group $\boldsymbol{A} 1$ - 10 years, Group B 11 - 20 years and Group $\boldsymbol{C}$ more than 20 years. Biopsies were taken from the viral warts lesions, solar keratosis and associated skin malignancies.

One 100 healthy individuals, 70 males, 30 females, their ages ranged from $14-73$ years, a mean \pm SD of was $41.63 \pm 9.55$ years, had been examined as a control for the presence of viral warts and tumors. This control group had been collected from general population in multiple regions in Baghdad City.

Formal consent was taken from each patient after full explanation about the goal and nature of the present study. Also, ethical approval was performed by the Scientific Council of Dermatology and Venereology-Iraqi Board for Medical Specializations.

Statistical analysis were done using EPI-info version 6 by estimation of both descriptive and analytic statistics. $\mathrm{P}$ value equal or less than 0.05 was considered as significant.

\section{Results}

Forty patients out of one hundred kidney transplant pa- tients had viral warts, their ages ranged from $22-70$ years with a mean \pm SD of $39.27 \pm 10.62$ years, 34 males and 6 females, and the duration of the warts ranged from 0.3 - 15 years with a mean \pm SD of $4.64 \pm 3.66$ years. The distribution of patients with viral warts among the groups was as follows: Group $\boldsymbol{A} 28$ (70\%), Group B 7 (17.5\%), Group $C 5(12.5 \%)$ cases. While viral warts seen only in $9(9 \%)$ individuals of control group. There was statistically significant difference between patients and control cases ( $\mathrm{P}$ value $<0.00001)$. Most of the viral warts in patients with kidney transplantation were numerous, larger in size and of the verrucae vulgaris type. They were mainly located on the exposed areas of the body, mostly on the face and dorsa of hands.

Viral warts admixed up with solar keratosis and skin malignancies were observed in 14 out of 100 kidney transplant patients: their ages ranged from $35-70$ years with a mean \pm SD of $54.28 \pm 9.35$ years and the duration of solar keratosis ranged from 0.5 - 25 years with a mean $5.54 \pm 3.34$ years.

The distribution of patients with solar keratosis among the groups were as follow: Group $A 4$ (28.58\%), Group B 5 (35.71\%), Group $C 5(35.71 \%)$ cases. While solar keratosis seen in $1(1 \%)$ individual in a control group. Skin malignancies in these fourteenth patients with combined viral warts and solar keratosis were observed in 6 (42.14\%) cases: 2 squamous cell carcinoma and 4 basal cell carcinoma. These skin malignancies were mainly located on the exposed areas of the body, mostly on the face and dorsa of the hands. No cases were seen in Group $\boldsymbol{A}$, while three $(60 \%)$ cancer cases in Group $B$ and three $(60 \%)$ patients in Group $\boldsymbol{C}$. No skin malignancies were observed in control group (Figures 1 and 2).

\section{Discussion}

Kidney transplant recipients receive multiple immuno-

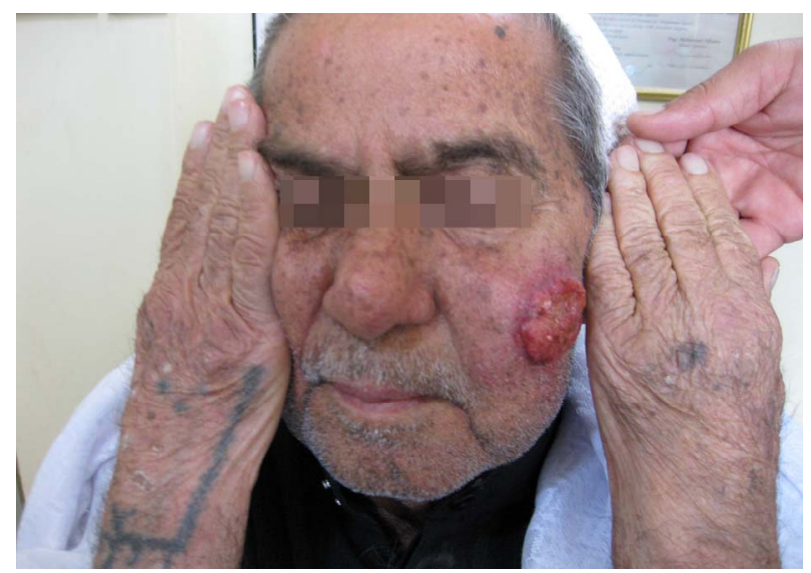

Figure 1. Sixty-seven years old male patient with kidney transplant showing multiple solar keratosis with big squamous cell carcinomaon the left cheek. 


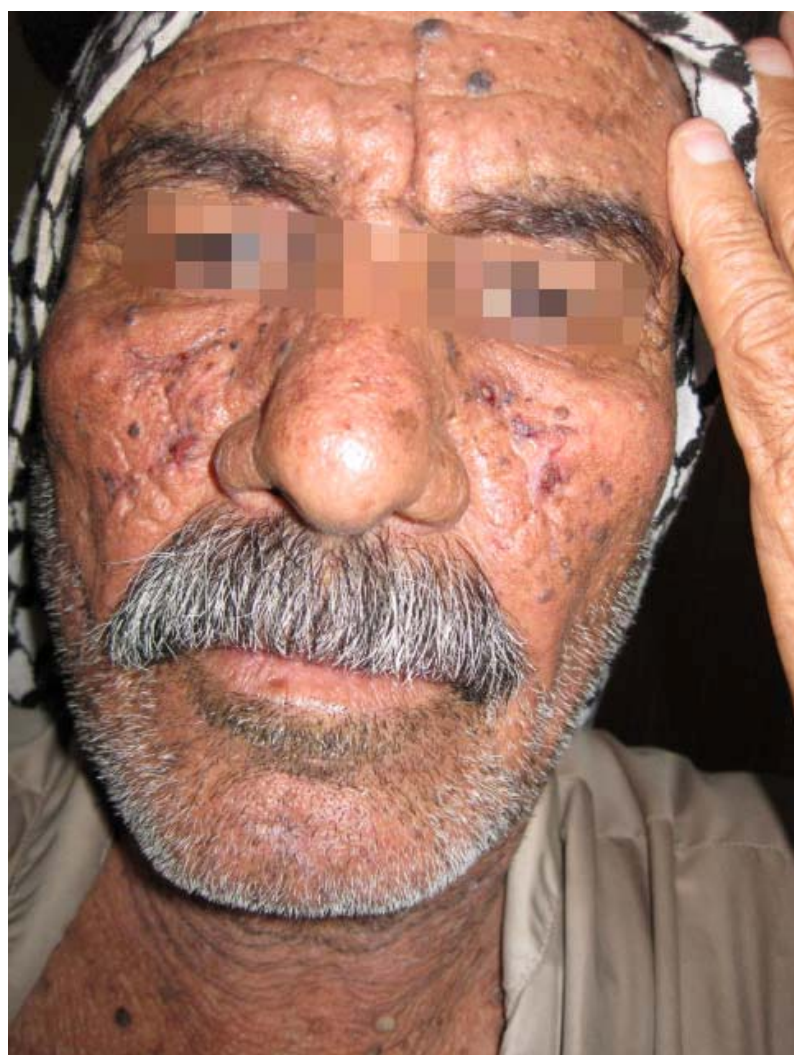

Figure 2. Sixty five years old patient with kidney transplant showing numerous solar keratosis admixed up with many basal cell carcinomas.

suppressive drugs that are used to prevent organ rejections $[10,11]$. This immunosuppression usually ends with increase tendency for infections especially viral warts [11].

The present work showed that viral warts had been found in $40 \%$ of kidney transplant patients, while viral warts admixed up with solar keratosis found in 14 (14\%) of cases and sometimes it is not easy to differentiate between viral warts and solar keratosis as they could be similar and mixed up with each other's especially in late cases. Skin malignancies mainly squamous cell carcinoma and basal cell carcinoma were seen in $6(6 \%)$ cases of kidney transplant patients in combination with viral warts and solar keratosis. In all cases, these lesions were observed on the sun exposed areas mainly face. This increase in rate of malignancies among patients with kidney transplantations was similar to what has been published [4,12-15].

In a previous Iraqi study, viral warts were reported in $50 \%$ of patients with kidney transplant while skin malignnancies was seen in $4.6 \%$ of cases (six cases: one $\mathrm{BCC}$ and five SCC) in comparison with the present work $6(42.14 \%)$ of cases (four BCC, two SCC). The present study showed very important observation as over years of immunosuppressive therapies, the number of viral warts decreased while the number of solar keratosis together with skin malignancies were increased. This was almost similarly reported [10].

Inherited EV is usually autosomal recessive disease, that associated with early onset of numerous viral warts similar to pigmented pityrasis rosea or tinea versicoler like lesions [1-4] with high tendency to develop skin malignancies especially squamous cell carcinoma in 30\% $60 \%$ of cases. They begin to appear at ages $20-40$ years [4]. Most of the malignant tumors remains local, but regional \& distant metastasis may occur [1-3]. The serotypes of HPV that responsible for this oncogensity are 5, 8 and 47 types [1-4,6,9].

It is well known that EV associated with skin malignancies like squamous cell carcinoma and basal cell carcinoma and HPV types 5,8 and 47 have been incriminated in their etiopathogenesis [1-4,6,9]. Most recently, it has been observed that HPV had contributed in the development of squamous cell carcinoma even in patients without viral warts $[16,17]$. So, HPV in patients with kidney transplant could act as a co-factor in the tumor development along with immunosuppresion, solar radiation and other environmental factors $[1-4,14]$.

In reviewing, the clinical picture of the inherited EV in comparison with that of the clinical features in patients with kidney transplant, we found the following similar observations in both conditions: There is immunosuppression because of impaired cell mediated immunity, the rash occurs in young patients, there are numerous skin lesions, they are recalcitrant to therapy, viral warts and skin cancers occur on any parts of the body especially in sun exposed areas of the body and skin malignnancies is a common feature $[1-10,15,17-20]$. The serotypes of human papilloma virus of viral warts and malignancies in patients with kidney transplant is similar to serotypes of HPV found in the inherited epidermodysplasia verruciformis, these HPV types include HPV$3,5,8,9,10,12,14,15,17,19,25$ and 36 through 38 $[17,21,22]$.

So, the infective agents, the immune defect, clinical pictures of the skin rash and the course of the disease in kidney transplant recipients having many similarities with that of the inherited form of EV [13-20]. These clinical pictures in patients with kidney transplant have been described as acquired epidermodysplasia verruciformis. The present work had supported the features of this new entity so called acquired epidermodysplasia verruciforms [10].

Cytotoxic drugs can induce skin malignancies in patients with solid organ transplants especially in patients with kidney transplant and this in collaboration with other factors like fair skin, UV light exposure, and HPV infections [10,23-28]. Accordingly these patients should be protected from sun light exposure and even could be 
immunized against HPV infections before doing organ transplant and giving cytotoxic drugs for prolonged course.

In conclusion, the features of viral warts, solar keratosis and skin malignancy were recorded in patients with kidney transplant and deserved the term acquired epidermodysplasia verruciforms as has been reported [10].

\section{REFERENCES}

[1] J. C. Sterling and J. B. Kurtz, "Viral Infections," In: R. H. Champion, J. L. Burton and D. A. Burn, Eds., Rook's Textbook of Dermatology, Blackwell Science Ltd. Editorial Office, Oxford, 1998, pp. 995-1095.

[2] N. Penneys, "Diseases Caused by Viruses," In: D. Elder, R. Elenitsas, C. Jaworsky and B. Johnson Jr., Eds., Lever's Histopathology of the Skin, W.B. Saunders Company, Philadelphia, 1997, pp. 569-589.

[3] D. R. Lowy and E. J. Androphy, "Warts," In: I. M. Freedberg, A. Z. Eisen, K. Wolff, K. F. Austen, L. A. Goldsmith and S. I. Katz, Eds., Fitzpatrick's Dermatology in General Medicine, The McGraw-Hill Companies, New York City, 2003, pp. 2119-2131.

[4] R. B. Odom, W. D. James and T. G. Berger, "Viral, Diseases," In: Andrew's Diseases of the Skin: Clinical Dermatology, W.B. Saunders Company, Philadelphia, 2000, pp. 473-525.

[5] R. S. Ostrow, D. Manias, A. J. Mitchell, L. Stawowy and A. J. Faras, "Epidermodysplasia Verruciformis. A Case Associated with Primary Lymphatic Dysplasia, Depressed Cell-Mediated Immunity, and Bowen's Disease Containing Human Papillomavirus 16 DNA," Archives of Dermatology, Vol. 123, No. 11, 1987, pp. 1511-1516.

[6] H. Pfister, "Human Papillomaviruse and Impaired Immunity vs Epidermodysplasia Veruciformis," Archives of Dermatology, Vol. 123, No. 11, 1987, pp. 1469-1470. doi:10.1001/archderm.1987.01660350069015

[7] M. Yutsudo, T. Tanigaki, R. Kanada, T. Sasagawa, T. Inoue, P. Jing, I. I. H. Yong and A. Hakura, "Involvement of the Human Papilloma Viruse Verruciformis Skin Carcinogenesis," Journal of Clinical Microbiology, Vol. 32, No. 4, 1994, pp. 1076-1078.

[8] S. Majewski, E. Skopinska-Rozewska, S. Jablonska, M. Wasik and J. Misiewicz, "Partial Defects of Cell-Mediated Immunity in Patients with Epidermodysplasia Verruciformis," Journal of the American Academy of Dermatology, Vol. 15, No. 5, 1986, pp. 966-973. doi:10.1016/S0190-9622(86)70258-2

[9] G. Orth, "Epidermodysplasia Verruaformis: A Model for Understanding the Oncogensity of Human Papilloma Viruses," Ciba Foundation Symposium, Vol. 120, 1986, pp. 157-174.

[10] K. E. Sharquie, S. A. Al-Mashhadani, A. A. Noaimi and M. Y. Abbas, "Acquired Epidermodysplasia Verruciformis in Kidney Transplant Patients," Journal of the Saudi Society of Dermatology \& Dermatologic Surgery, Vol. 15, No. 2, 2011, pp. 53-56.

[11] D. Hamilton, “A Kidney Transplantation: A History,” In:
P. J. Morris, Ed., Kidney Transplantation Principles and Practice, W.B. Saunders Company, Philadelphia, 1988, pp. 1-11.

[12] G. Rowan, R. G. Walker and J. F. Antony, "A 2 Azthioprine and Steroids," In: P. J. Morris, Ed., Kidney Transplantation, Principles and Practice, W.B. Saunders Company, Philadelphia, 1988, pp. 319-399.

[13] R. Rudlinger, I. W. Smith, M. H. Bunney and J. A. Hunter, "13-Human Papilloma Virus Infections in a Group of Renal Transplant Recipients," British Journal of Dermatology, Vol. 115, No. 6, 1986, pp. 681-692. doi:10.1111/j.1365-2133.1986.tb06649.x

[14] I. M. Leigh and M. T. Glover, "Skin Cancer and Warts in Immuno Suppressed Renal Transplant Recipients," Recent Results in Cancer Research, Vol. 139, 1995, pp. 6986. doi:10.1007/978-3-642-78771-3 6

[15] I. M. Leigh and M. T. Glover, "Cutaneous Warts and Tumors Inimmunosuppressed Patients," Journal of the Royal Society of Medicine, Vol. 88, No. 2, 1995, pp. 6162.

[16] K. E. Sharquie and S. A. Al-Sadawi, "Cutaneous Manifestations in Renal Transplant Recipients among Iraqi Patients," Iraqi Journal of Community Medicine, Vol. 14, No. 1, 2001, pp. 1-4.

[17] K. Murao, Y. Kubo, K. Fukubara, K. Mastsumoto and S. Arape, "Three Cases of Bowen's Disease on the Lower Abdomen with High Risk Types 16, 33 and 59 of HPVs," Journal of the American Academy of Dermatology, Vol. 52, No. 4, 2004, pp. 723-724.

[18] L. M. De Jong-Tieben, R. J. Berkhout, H. L. Smits, J. N. Bouwes Bavinck, B. J. Vermeer, F. J. van der Woude and J. ter Schegget, "High Frequency of Detection of Epidermodysplasia Verruciformis Associated Human Papilloma Viruses DNA Detection in Biopsies from Malignant and Pre Malignant Lesions from Renal Transplant Recipient," Journal of Investigative Dermatology, Vol. 105, No. 3, 1995, pp. 367-371.

[19] A. Annelies, A. Peter and B. Martina, "Skin Changes and Tumors after Renal Transplantation," Clinical Issues in Nephrology, Vol. 91, No. 2, 2002, pp. 188-196. doi:10.1159/000058391

[20] R. Jeffrey, L. Edgar and A. Reza, "Cutaneous Neoplasm in Renal Transplant Recipients," European Journal of Dermatology, Vol. 12, No. 6, 2000, pp. 532-535.

[21] V. Shamanin, M. Glover, C. Rausche, C. Proby, I. M. Leigh, H. zur-Hausan and E. M. de-Villiers, "Specific Types of Human Papillomavirus Found in Benign Proliferation and Carcinoma of the Skin in Immunosuppressed Patients," Cancer Research, Vol. 54, No. 17, 1994, pp. 46104613.

[22] J. Doorbar, "Specific Interaction between HPV-16 EI-E4 and Cytokeratins Results in Collapse of the Epithelial Cell Intermediate Filament Network," Nature, Vol. 352, 1991, p. 824. doi:10.1038/352824a0

[23] L. M. Tieben, R. J. Berkhout, H. L. Smits, et al., "Detection of Epidermodysplasis Verruciformis-Like Human Papilloma Virus Types in Malignant and Premalignant Skin Lesions of Renal Transplant Recipients," British Journal 
of Dermatology, Vol. 131, No. 2, 1994, pp. 226-230.

[24] I. Penn, "Cancers in Cyclosporine Treated vs. Azathioprine Treated Patients," Transplantation Proceedings, Vol. 28, No. 2, 1996, pp. 876-878.

[25] A. E. Taylor and S. Shuster, "Skin Cancer after Renal Transplantation: The Causal Role of Azathioprine," Acta Dermato-Venereologica, Vol. 72, No. 2, 1992, pp. 115119.

[26] C. M. Perrette, S. L. Walker, P. O’Donovan, J. Warwick, C. A. Harwood, P. Karran and J. M. McGregor, "Azathioprine Treatment Photosensitive Human Skin to Ultraviolet a Radiation," British Journal of Dermatology, Vol. 159, No. 1, 2008, pp. 198-204. doi:10.1111/j.1365-2133.2008.08610.x
[27] L. Peyrin-Biroulet, K. Khosrotehrani, F. Carrat, A. M. Bouvier, J. B. Chevaux, T. Smon, F. Carbonnel, J. F. Colombel, J. L. Dupas, P. Godeberege, J. P. Hugot, M. Lemann, S. Nahon, J. M. Sabate, G. Tucat, L. Beaugerie and Cesame Study Grpup, "Increased Risk for Nonmelanoma Skin Cancers in Patients Who Receive Thiopurines for Inflammatory Bowel Disease," Gastroenterology, Vol. 141, No. 5, 2011, pp. 1621-1628.

[28] K. E. Sharquie, A. A. Noaimi and S. Y. Mohsin, "Frequency of Autoimmune Diseases and Estimation of P53 among Vitiligo Patients," Thesis for Fellowship of Iraqi Board for Medical Specializations in Dermatology and Venerevlogy, Iraqi Board for Medical Specializations, Baghdad, 2011. 